\title{
Talk Shows and Leaflets Improve Senior High School Student Knowledge of Chronic Kidney Diseases
}

\author{
Laurencia Imelda, ${ }^{1}$ Rudi Supriyadi, ${ }^{2}$ Yenni Zuhairini ${ }^{3}$ \\ ${ }^{1}$ Faculty of Medicine Universitas Padjadjaran, Indonesia, ${ }^{2}$ Departement of Internal Medicine \\ Faculty of Medicine Universitas Padjadjaran/Dr. Hasan Sadikin General Hospital Bandung, \\ Indonesia, ${ }^{3}$ Department of Public Health Faculty of Medicine Universitas Padjadjaran, Indonesia
}

\section{Abstract}

Background: The increase of chronic kidney disease (CKD) incidence and its related costs in developing countries have urged all levels of society prevent this disease. Prevention can be effectively done when someone has good knowledge about the disease. This study aimed to observe the change in knowledge about CKD before and after education sessions in the form of talk shows as well as through the leaflet media among senior high school students.

Methods: This was a cross-sectional observational quantitative study on 71 first-grade students participated in World Kidney Day 2019 event. The questionnaire was distributed before and after the education program and data collected were analyzed using the Wilcoxon-signed rank test and MannWhitney test to explore changes in the level of knowledge based on the characteristics of the subjects. Results: In total, 158 severe HA patients and 21 severe HB patients were included with a median bleeding The median level of student knowledge before education was 76\% (16-96\%), which increased to $92 \%(28-100 \%)$ after education $(\mathrm{p}<0.001)$. No significant correlation was observed between knowledge about CKD and gender $(\mathrm{p}=0.486)$, family history of CKD $(\mathrm{p}=0.281)$, and health workers as parents $(\mathrm{p}=0.543)$.

Conclusions: There is a significant improvement in knowledge of CKD before and after an education session through talk shows and leaflets among senior high school students. Health educations need to be regularly given to young adolescents using different approaches to increase their knowledge about various topics.

Keywords: Chronic kidney disease, knowledge, leaflet, students, talk show

\section{Introduction}

Chronic kidney disease (CKD) is defined as an impaired kidney function or structure that has lasted for more than 90 days. ${ }^{1}$ A metaanalysis has shown a global prevalence of CKD of $11-13 \% .^{2}$ In Indonesia, the prevalence of CKD reached $12.5 \%$ based on a study that was conducted by Perhimpunan Nefrologi Indonesia (PERNEFRI) in 2006. ${ }^{3}$ The increase of CKD events from year to year was shown in the result of Riset Kesehatan Dasar (Riskesdas), from $0.2 \%$ in 2013 to $0.38 \%$ in $2018 .{ }^{4}$ In 2014 , West Java was ranked as the $8^{\text {th }}$ province with a highest CKD prevalence in Indonesia. ${ }^{4}$ Chronic kidney disease as an irreversible disease that lasts for a lifetime was ranked as the $18^{\text {th }}$ leading cause of global deaths according to the Global Burden Disease Study in 2010. ${ }^{1}$

Management of CKD patients, especially patients with terminal kidney disease, raises new problems. Health service resources and existing health budgets in developing countries often cannot meet the needs of the community for the management of chronic kidney disease which is quite expensive. ${ }^{5}$ Kidney disease financing is still the secondlargest Badan Penyelenggara Jaminan Sosial (BPJS) health financing after heart disease in Indonesia until 2015. ${ }^{3}$ The existence of CKD as a burden of developing countries and its increasing prevalence require other approaches to deal with this disease. . $^{2,5,6}$ Health promotion is important and relevant in

Correspondence: Laurencia Imelda, Faculty of Medicine, Universitas Padjadjaran, Jalan Raya Bandung-Sumedang Km. 21, Jatinangor, Sumedang, Indonesia, E-mail: mellaurensia@gmail.com 
today's situation to empower individuals and communities to take action for their health. ${ }^{7}$ Prevention and awareness-raising need to be preceded by good knowledge to run effectively. A study conducted in Australia in 2018 showed that public knowledge about CKD was low. ${ }^{8}$ This condition has to be improved because behavior based on knowledge will last longer than behavior without a knowledge base. ${ }^{9}$

Health education is an effort to deliver health messages to the public to gain knowledge and better health behavior. ${ }^{9}$ Education can be done in various ways such as counseling, lecture, or seminar. ${ }^{9}$ World Kidney Day is a campaign that is carried out simultaneously throughout the world every Thursday the second week in March as a moment to educate the public about the importance of kidney health. World Kidney Day in 2019, especially in West Java, was filled with providing education to senior high school students, especially Public Senior High School (Sekolah Menengah Atas Negeri) 3 Bandung, as early prevention in adolescents. Through this opportunity, the study was carried out to analyze the difference of senior high school students' knowledge about CKD before and after receiving education with both talk show and leaflet as an information media.

\section{Methods}

An observational cross-sectional study was conducted at a high school in Bandung. The questionnaire was distributed before and after education about chronic kidney disease. A total sampling was employed with minimum samples 53, and this study met the criteria by including 71 first-year students who participated in the World Kidney Day 2019 event.

Incomplete data of the respondents and missing answers of the questionnaire were excluded. The independent variable in the study was education with the talk show method and leaflet as the information media. The dependent variable was knowledge about CKD of the students. Confounding variables in the study were family history of kidney disease and parents' occupation.

The questionnaire consisted of 25 questions, divided into six groups. Some questions in the questionnaire were adapted from a validated questionnaire used in a previous study. 8 The correct answer was given 1 point and the wrong answer or 'don't know' were given 0 points. The final score was calculated as a percentage.

Data were collected after obtaining ethical approval from the Research Ethics Committee Universitas Padjajaran Bandung (No.1000/ UN.6/KEP/EC/2019). The knowledge scores were analyzed by paired T-test if the data were normally distributed or by the Wilcoxon signed-rank test if the data were not normally distributed to explore whether there were significant differences in the level of knowledge before and after education. The MannWhitney test was used further to observe any difference in the level of knowledge based on the characteristics of the subjects.

\section{Results}

In total, 71 students had met the inclusion criteria, consisting of females $(64.8 \%)$ as shown in Table 1. Most students (95.8\%)

Table 1 Characteristic of Senior High school Students

\begin{tabular}{lc}
\hline \multicolumn{1}{c}{ Characteristics } & $\mathbf{n}(\%)$ \\
\hline Gender & $25(35.2)$ \\
Male & $46(64.8)$ \\
Female & $15(13-17)$ \\
Age (years), median (min-max) & \\
Family history of CKD, n\% & $3(4.2)$ \\
Yes & $68(95.8)$ \\
No & \\
Parents' Occupation, n(\%) & $9(12.7)$ \\
Health workers & $62(87.3)$ \\
$\quad$ Non-health workers
\end{tabular}

Note: $\mathrm{CKD}=$ chronic kidney disease 
Table 2 Percentage of Correct Answers among Senior High School Students about Chronic Kidney Disease

\begin{tabular}{|c|c|c|}
\hline \multirow{2}{*}{ Questions } & \multicolumn{2}{|c|}{ Correct Answers, n(\%) } \\
\hline & Before Education & After Education \\
\hline Kidneys Function & $(69.86 \%)$ & $(78.87 \%)$ \\
\hline 1. Urine production & $71(100 \%)$ & $71(100 \%)$ \\
\hline 2. Maintain blood pressure & $47(66.1 \%)$ & $62(87.3 \%)$ \\
\hline 3. Spread fluid throughout the body & $26(36.6 \%)$ & $24(33.8 \%)$ \\
\hline 4. Promote red blood cell formation & $34(47.9 \%)$ & $52(73.2 \%)$ \\
\hline 5. Blood filtration & $70(98.6 \%)$ & $71(100 \%)$ \\
\hline Clinical Manifestations of CKD & $(65.91 \%)$ & $(69.86 \%)$ \\
\hline 6. High blood pressure & $49(69 \%)$ & $71(100 \%)$ \\
\hline 7. Lower back pain & $49(69 \%)$ & $64(90.1 \%)$ \\
\hline 8. Itching & $20(28.2 \%)$ & $48(67.6 \%)$ \\
\hline 9. Change in urinary frequency and quantity & $63(88.7 \%)$ & $65(91.5 \%)$ \\
\hline 10. Foamy urine & $53(74.6 \%)$ & $70(98.6 \%)$ \\
\hline Risk Factors of CKD & $(77.93 \%)$ & $(97.18 \%)$ \\
\hline 11. Hypertension & $54(76 \%)$ & $71(100 \%)$ \\
\hline 12. Diabetes Mellitus & $61(85.9 \%)$ & $68(95.8 \%)$ \\
\hline 13. Smoking & $51(71.8 \%)$ & $68(95.8 \%)$ \\
\hline Kidneys Health Examination & $(68.07 \%)$ & $(73.23 \%)$ \\
\hline 14. Blood test (creatinine, ureum level, GFR) & $64(90.1 \%)$ & $71(100 \%)$ \\
\hline 15. Urine test (albumin/protein) & $66(92.9 \%)$ & $70(98.6 \%)$ \\
\hline 16. Faecal test & $15(21.1 \%)$ & $15(21.1 \%)$ \\
\hline CKD Prevention & $(88.38 \%)$ & $(97.53 \%)$ \\
\hline 17. Stop smoking and avoid cigarette smoke & $60(84.5 \%)$ & $69(97.2 \%)$ \\
\hline 18. Maintain water intake & $69(97.2 \%)$ & $70(98.6 \%)$ \\
\hline 19. Maintain normal blood glucose & $64(90.1 \%)$ & $68(95.8 \%)$ \\
\hline 20. Maintain normal blood pressure & $58(81.7 \%)$ & $70(98.6 \%)$ \\
\hline Management of CKD & $(60 \%)$ & $(82.53 \%)$ \\
\hline 21. Sodium intake restriction & $44(62 \%)$ & $69(97.1 \%)$ \\
\hline 22. Fluid intake restriction & $38(53.5 \%)$ & $51(71.8 \%)$ \\
\hline 23. Calorie intake restriction & $34(47.9 \%)$ & $53(74.6 \%)$ \\
\hline 24. Protein intake restriction & $41(57.7 \%)$ & $53(74.6 \%)$ \\
\hline 25. Restriction of herbs/drugs consumption & $56(78.9 \%)$ & $67(94.4 \%)$ \\
\hline
\end{tabular}

Note: $\mathrm{CKD}=$ chronic kidney disease

stated no family history of CKD. Some students had parents who worked as health workers, namely doctors, dentists, midwives, and pharmacists.

The level of knowledge about CKD was measured using a questionnaire consisting of 25 questions and divided into six groups. The percentage of correct answers to each question was shown in Table 2. The largest percentage of correct answers was found in 
Table 3 Correlation of Characteristics of Senior High School Students and Pre-educational Scores

\begin{tabular}{|c|c|c|c|}
\hline Characteristics & Total, n (\%) & $\begin{array}{c}\text { Pre-education } \\
\text { scores, median } \\
\text { (min-max) }\end{array}$ & p Value \\
\hline \multicolumn{4}{|l|}{ Gender: } \\
\hline Male & $25(35.2 \%)$ & $76(28-92)$ & $0.486^{*}$ \\
\hline Female & $46(64.8 \%)$ & $72(16-96)$ & \\
\hline \multicolumn{4}{|l|}{ Family history of CKD: } \\
\hline Yes & $3(4.2 \%)$ & $60(28-84)$ & $0.281^{*}$ \\
\hline No & $68(95.8 \%)$ & $76(16-96)$ & \\
\hline \multicolumn{4}{|l|}{ Parents' Occupation: } \\
\hline Health workers & $9(12.7 \%)$ & $84(28-92)$ & $0.543^{*}$ \\
\hline Non-health workers & $62(87.3 \%)$ & $74(16-96)$ & \\
\hline
\end{tabular}

Note: *Mann-Whitney test; $\mathrm{CKD}=$ chronic kidney disease

a group of questions about the prevention of CKD with the percentage of correct answers was $88.93 \%$ before education.

Before receiving education, all students already knew that the kidneys were organs that play a role in the production of urine. The percentage of correct answers in the group of questions about symptoms of CKD exceeded $60 \%$, except for the question about itching as one of CKD symptoms with correct answers of $28.2 \%$. A total of 56 students $(78.9 \%)$ did not know that examination of kidney function cannot be done through a stool examination. That question became a question with the smallest correct answers percentage.

The increase in the percentage of correct answers occurred on almost all questions after the students received an education, except for the question about kidney that did not play a role in spreading fluids throughout the body which decreased to $33.8 \%$ and questions about examining kidney function through feces that did not have percentage change in the number of correct. The highest increase in the percentage of correct answers was found in the group of questions about the management of CKD, which increased by $22.53 \%$.

The correlation between subject characteristics and the level of knowledge about CKD before education was shown in Table 3. Statistical tests showed no significant knowledge level difference between female and male students before education $(\mathrm{p}=0.486)$. The existence of a family history of kidney disease ( $p=0.281$ ) and parents' occupation as health workers $(\mathrm{p}=0.543)$ had no significant relationship with the level of knowledge about CKD.

The final scores of the knowledge before and after education was tested with Kolmogorov-Smirnov and did not show normal distribution. The median level of students' knowledge before education was 76\% (16$96 \%$ ) and increased to $92 \%$ (28-100\%) after education. A comparison test using a Wilcoxon signed-rank test showed p-value of $<0.001$. There are 55 subjects with an increased level of knowledge, 7 subjects with the same level of knowledge, and 9 subjects with a decreased level of knowledge after education. The study showed significant differences in the level of students' knowledge before and after education.

\section{Discussion}

Knowledge is everything that someone knows as the result of someone's senses or intellect. ${ }^{9}$ The knowledge level examined in this research is the knowledge of students before and after receiving intervention in the form of education by talk show and leaflet as media, which has been assessed based on students' ability to answer questions correctly. The study has shown that the knowledge of students regarding chronic kidney disease was $76 \%$. The score is greater than some studies which were conducted in other countries that also examined the level of knowledge about CKD in the community and students. ${ }^{8,10,11}$ This score is similar to a study of students at a university in Australia, which is $79 \% .{ }^{8}$ The higher score 
in this study compare to other studies in the community is likely due to the educational background that the respondents all are high school students and have received lessons about biology at school.

The knowledge can be influenced by several factors, including age, experience, level of education, and source of information. ${ }^{9}$ A research conducted in the families of hemodialysis patients, shows that families with diagnosed CKD members have good knowledge about CKD. ${ }^{12}$ This is also similar to a study conducted in Australia which showed a correlation between CKD experience in the family and better knowledge about $\mathrm{CKD}^{8}$ Different from previous studies, this study has found no significant differences in the level of knowledge between students with and without a family history of CKD. This result shows that the students have not got enough information about CKD from the family even though there is family member who has experienced related to CKD. The correlation between education level and students' knowledge of CKD is not measured in this study because of the uniform characteristics of the respondents. This study provides an overview of the level of knowledge about CKD at the level of high school education. Sources of information on this research are health education given by talk shows and leaflets as the information media. Beside them, the information could also be obtained through non-media sources such as parents, family, friends, and health workers. ${ }^{9}$ This study shows no significant difference between the level of knowledge of students whose parents worked as health workers and non-health workers. The result showed that parents who worked as health workers also apparently had not given enough information about CKD to their children.

Improvement in students' knowledge about CKD after receiving an education was the result of education provided through interactive talk shows and leaflets as information media. Media has an important role in process of teaching and learning, not only just as teacher complement but also as a determinant of teaching success. ${ }^{13}$ It is also determined by the teacher's ability to choose the media. ${ }^{13}$ Education with talk show method was considered more suitable and interesting given to high school students. Education through seminars, which was modified to be an interactive talk show in this study, is an educational method that is considered effective in a large group. ${ }^{9}$ The existence of media such as leaflets could also help the education process and assisted students in re-learning the material that had been delivered. This result is consistent with which showed that education with the lecture method accompanied by leaflets or booklets has a greater influence than education with just the lecture method. ${ }^{14}$ Education by using audiovisual media such as video and leaflets had an impact on improving knowledge of adolescents. ${ }^{15}$ There were students with posteducational scores that are equal to or even smaller compared to pre-educational scores. This might be due to the lack of student attention in listening and following the education provided.

The limitation of this study is that the study only involved students in one high school as participants of World Kidney Day 2019, who were all first grade of science class students. Therefore, the research might not adequately represent the level of knowledge of high school students as a whole. The data collected in the form of self-administered questionnaires which brings up some weaknesses such as questionnaires that were not properly filled out by the subjects. This study also has not yet measured other factors that can influence the subjects' level of knowledge about CKD.

To conclude, there is an improvement in knowledge among high school students about CKD after receiving education with talk show methods and leaflets as media. Further studies with a broader range of respondents are needed to describe the knowledge about CKD among teenagers. Other factors that can influence the knowledge about CKD should also be considered in future studies. The results of this study can be used as a reference for the government, health workers, and related parties to enhance the education and prevention of CKD in the community.

\section{Acknowledgement}

We are grateful to high school students from SMA Negeri 3 Bandung for their participation in this study.

\section{References}

1. Kidney Disease: Improving Global Outcomes (KDIGO) CKD Work Group. KDIGO 2012 clinical practice guideline for the evaluation and management of chronic kidney disease. Kidney Inter Suppl. 2013;3(1):1-150.

2. Hill NR, Fatoba ST, Oke JL, Hirst JA, O'Callaghan CA, Lasserson DS, et al. Global prevalence of chronic kidney disease-a systematic review and meta-analysis. 
PLOS ONE. 2016;11(7):e0158765

3. Pusat Data dan Informasi Kementrian Kesehatan Republik Indonesia. Situasi penyakit ginjal kronis. Jakarta: Pusat Data dan Informasi Kementrian Kesehatan Republik Indonesia; 2017.

4. Badan Penelitian dan Pengembangan Kesehatan Kementrian Kesehatan Republik Indonesia. Hasil utama Riskesdas 2018. Jakarta: Badan Penelitian dan Pengembangan Kesehatan Kementrian Kesehatan Republik Indonesia; 2018.

5. Nugent RA, Fathima SF, Feigl AB, Chyung D. The burden of chronic kidney disease on developing nations: a 21st century challenge in global health. Nephron Clin Pract. 2011;118(3):269-77.

6. Khalil A, Abdalrahim M. Knowledge, attitudes, and practices towards prevention and early detection of chronic kidney disease. Int Nurs Rev. 2014;61(2):237-45.

7. Ali A, Katz DL. Disease prevention and health promotion: how integrative medicine fits. Am J Prev Med. 2015;49(5 Suppl 3):S230-40.

8. Gheewala PA, Peterson GM, Zaidi STR, Jose MD, Castelino RL. Public knowledge of chronic kidney disease evaluated using a validated questionnaire: a cross-sectional study. BMC Public Health. 2018;18(1):371.

9. Notoatmodjo S. Pendidikan dan perilaku kesehatan. Jakarta: PT Rineka Cipta; 2003.

10. Oluyombo R, Ayodele OE, Akinwusi PO,
Okunola 00, Gbadegesin BA, Soje MO, et al. Awareness, knowledge and perception of chronic kidney disease in a rural community of south-west nigeria. Niger J Clin Pract. 2016;19(2):161-9.

11. Avery NW, Leggett SS, Juncos LA. Strengthening chronic kidney disease knowledge among students attending a historically black university. The Journal of Nephrology Social Work. 2016;40(2):3843.

12. Noviriyanti D, Hasibuan P, Handini M. Tingkat pengetahuan, sikap, dan tindakan keluarga pasien hemodialisis mengenai gagal ginjal kronik di RSUD Dokter Soedarso Pontianak. Jurnal Mahasiswa PSPD FK Universitas Tanjungpura. 2014;1(1).

13. Mahnun N. Media pembelajaran (kajian terhadap langkah-langkah pemilihan media dan implementasinya dalam pembelajaran). An-Nida': Jurnal Pemikiran Islam. 2012;37(1):27-33.

14. Safitri NRD, Fitrianti DY. Pengaruh edukasi gizi dengan ceramah dan booklet terhadap peningkatan pengetahuan dan sikap gizi remaja overweight. Journal of Nutrition College. 2016;5(4):374-80.

15. Meidiana R, Simbolon D, Wahyudi A. Pengaruh edukasi melalui media audio visual terhadap pengetahuan dan sikap remaja overweight. Jurnal Kesehatan. 2018;9(3):478-84. 